\title{
Enzyme immunoassay of pancreatic oncofetal antigen (POA) as a marker of pancreatic cancer
}

\author{
K NISHIDA, M SUGIURA, T YOSHIKAWA, AND M KONDO \\ From the First Department of Internal Medicine, Kyoto Prefectural University of Medicine, Kyoto, Japan
}

SUMMARY For the quantitative measurement of pancreatic oncofetal antigen (POA), an enzyme immunoassay for POA has been developed, and is based on the sandwich method using antibody-coupled glass beads and enzyme (peroxidase)-labelled antibody. Serum POA concentrations were increased significantly in patients with pancreatic cancer, but not in those with chronic pancreatitis or other miscellaneous diseases, or in normal subjects. It is concluded that the enzyme immunoassay could be used for the assay of POA and our results show that the determination of serum POA would be useful in the diagnosis of pancreatic cancer.

Presence of oncofetal antigen relatively specific to human pancreatic cancer, designated as pancreatic oncofetal antigen (POA), was first described by Banwo et al in 1974, ${ }^{1}$ and we have reported high positivity of POA in pancreatic juice of patients with pancreatic cancer by a qualitative assay method of double immunodiffusion or counter electroimmunophoresis. ${ }^{2}$

Attention has been focused on the detection of POA for the serological diagnosis of pancreatic cancer. Until now, however, assay of POA has not been used widely because a quantitative assay procedure for POA has not been established.

In this paper we describe a quantitative assay of POA using enzyme immunoassay, and its application as a clinical test for pancreatic cancer. ${ }^{3}$

\section{Methods}

\section{SUBJECTS}

Serum was collected from 21 patients with pancreatic cancer, in whom the diagnosis was confirmed by operation or necropsy, 28 patients with chronic pancreatitis, 74 patients with miscellaneous diseases including 37 patients with malignancy of the oesophagus, stomach, colon, biliary tract, or liver, and 46 healthy persons as normal controls.

PREPARATION OF ANTI-POA SERUM

Human fetal pancreatic tissue was obtained at about

Address for correspondence: Dr Koichi Nishida, First Department of Internal Medicine. Kyoto Prefectural University of Medicine. Kamikyoku. Kyoto. 602 Japan.

Received for publication 22 June 1984
23 weeks of fetal life and homogenised in a buffered solution containing protease inhibitors; 200 $\mathrm{KIE} / \mathrm{ml}$ of aprotinin and $60 \mathrm{mg} / \mathrm{ml}$ of epsilon aminocaproic acid (EACA). Homogenates were centrifuged at $100000 \times g$ for 50 minutes, and the pellet was discarded. After alpha-fetoprotein (AFP) was excluded by negative affinity chromatography with $\mathrm{CNBr}$ activated Sepharose 4B coupled with anti-AFP, the supernatant was emulsified with an equal volume of complete Freund's adjuvant to immunise rabbits by subcutaneous injection. The rabbits were bled when a sufficiently high antibody titre was achieved. The rabbit serum was absorbed with insolubilised normal human plasma, and adult and fetal human liver. ${ }^{4}$

\section{IgG FRACTION OF ANTISERUM}

The IgG fraction of the absorbed antiserum was isolated by ammonium sulphate precipitation, ${ }^{5}$ and by DEAE cellulose chromatography. ${ }^{6}$

\section{ANTIBODY COUPLED GLASS BEADS}

The rabbit (anti-POA) IgG-coupled glass beads were prepared by the method of Hamaguchi et al. ${ }^{7}$ Glass beads $(6.8 \mathrm{~mm}$ in diameter) were heated at $500^{\circ} \mathrm{C}$ for five hours, and then immersed in $2 \%$ solution of 3-aminopropyltriethoxysilane (Nakarai Ltd) in acetone at $40^{\circ} \mathrm{C}$ for 24 hours. The beads were washed with acetone and dried, and were then immersed in $1 \%$ aqueous solution of glutaraldehyde at room temperature for one hour. After washing with $0.25 \mathrm{M}$ sodium phosphate buffer, $\mathrm{pH} 7 \cdot 5,320$ beads were immersed in $50 \mathrm{ml}$ of $0.25 \mathrm{M}$ sodium phosphate buffer, $\mathrm{pH} 7 \cdot 5$, containing $2 \mathrm{mg}$ of rabbit 
IgG fraction isolated from anti-POA serum at $4^{\circ} \mathrm{C}$ overnight. After washing with $0.25 \mathrm{M}$ sodium phosphate buffer, $\mathrm{pH} 7 \cdot 5$, they were further immersed in $0.02 \mathrm{M}$ phosphate buffered saline (PBS), $\mathrm{pH} 7 \cdot 3$, containing $0 \cdot 1 \% \quad \mathrm{NaN}_{3}$ and $1 \%$ bovine serum albumin (BSA) (Fraction V, Nakarai Ltd), before storing at $4^{\circ} \mathrm{C}$.

\section{PEROXIDASE-LABELLED ANTIBODY}

The IgG fraction of anti-POA serum was coupled to horseradish peroxidase by the method of Nakane and Kawaoi. ${ }^{8}$ Five milligram of horseradish peroxidase (Grade II, RZ 3.4, $290 \mathrm{PU} / \mathrm{mg}$, Toyobo Ltd) was dissolved in $1.0 \mathrm{ml}$ of $0.3 \mathrm{M} \mathrm{NaHCO} 3, \mathrm{pH}$ $8 \cdot 1$, and $0 \cdot 1 \mathrm{ml}$ of $1 \%$ fluorodinitrobenzene (FDNB) in $99.5 \%$ ethanol was added and mixed gently at room temperature for one hour. Then $1.0 \mathrm{ml}$ of 0.06 $\mathrm{M} \mathrm{NaIO}_{4}$ in distilled water was added and mixed for 30 minutes at room temperature and $0.1 \mathrm{ml} 1.6 \mathrm{M}$ ethylene glycol in distilled water was further added and mixed gently for one hour at room temperature. The solution was dialysed against $0.01 \mathrm{M}$ sodium carbonate buffer, $\mathrm{pH} 9 \cdot 5$, at $4^{\circ} \mathrm{C}$ overnight. Five milligram anti-POA IgG was added to $3 \mathrm{ml}$ of the solution and mixed gently for three hours at room temperature and $5 \mathrm{mg} \mathrm{NaBH} 4$ was then added and mixed at $4^{\circ} \mathrm{C}$ for three hours. The solution was dialysed against $0.02 \mathrm{M}$ phosphate buffer, $\mathrm{pH} 7.3$, at $4^{\circ} \mathrm{C}$ overnight. The peroxidase conjugate was purified by Sephadex G-150 column chromatography, and fractions of peroxidase-labelled IgG were collected to which equal volumes of PBS containing $2 \%$ BSA were added before storing at $-40^{\circ} \mathrm{C}$.
PRINCIPLES OF THE METHOD

The POA enzyme immunoassay that we have developed is a solid phase enzyme immunoassay based on the sandwich principle, as illustrated in Figure 1. Glass beads coated with rabbit anti-POA were incubated with the samples. Pancreatic oncofetal antigen present in the samples was bound to the glass beads and unbound materials were removed by washing. Subsequently, anti-POA conjugated with peroxidase was incubated with the beads to form anti-POA-peroxidase conjugates on the beads which were then incubated with enzyme substrate to develop a colour which measured the amount of bound anti-POA-peroxidase conjugate. The enzyme reaction was stopped by the addition of sulphuric acid and the intensity of the colour developed was read using a spectrophotometer at $492 \mathrm{~nm}$. A standard curve was obtained by plotting against different concentrations of standard POA.

\section{ASSAY PROCEDURE}

Figure 2 shows an outline of the steps in the POA-enzyme immunoassay. One-tenth millilitre of the serum samples were incubated with antibodycoated glass beads in $0.2 \mathrm{ml}$ of buffer consisting of PBS containing $1 \% \mathrm{BSA}$ at $37^{\circ} \mathrm{C}$ for 12 hours. The beads were washed with $0.85 \%$ saline solution, and then incubated with $0.3 \mathrm{ml}$ of peroxidase-conjugated anti-POA at $37^{\circ} \mathrm{C}$ for three hours. After washing, the beads were transferred to $2 \mathrm{ml}$ of a substrate solution containing $0.8 \mathrm{mg}$ of o-phenylenediamine (Nakarai Ltd) and $0.2 \mu \mathrm{l} 30 \% \mathrm{H}_{2} \mathrm{O}_{2}$ in $0.1 \mathrm{M}$ citric acid with $0.2 \mathrm{M}$ dibasic sodium phosphate, $\mathrm{pH} 4.8$, before incubation at $37^{\circ} \mathrm{C}$ for 30 minutes. The

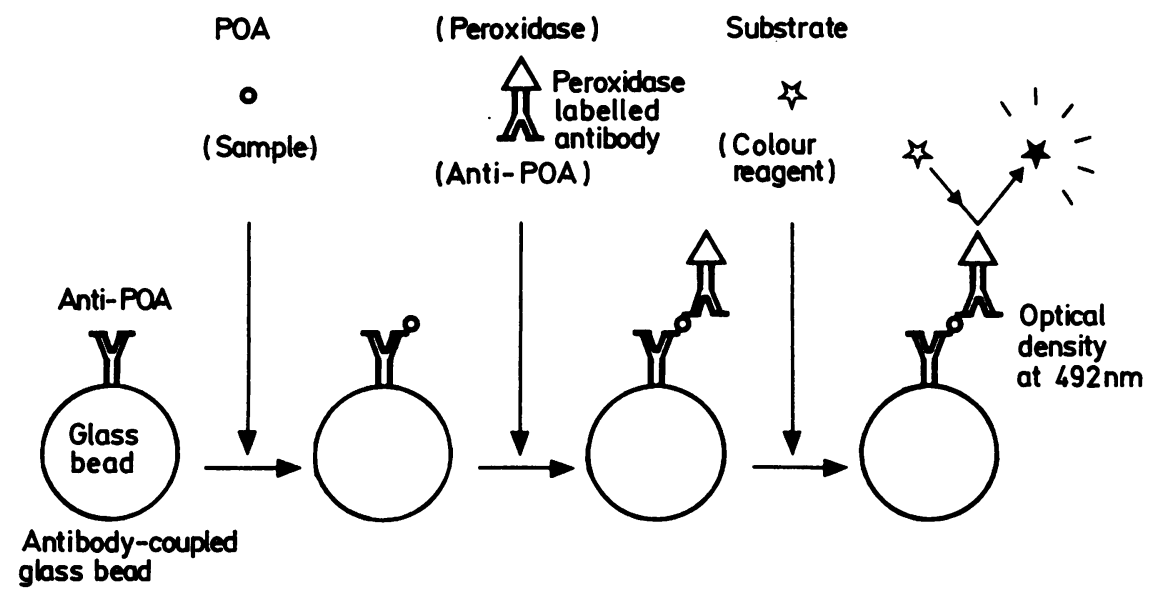

Fig. 1 Principle of the enzyme immunoassay for POA. 


\begin{tabular}{|lcc|}
\hline & Standards & Samples \\
\hline Standard POA & $0.1 \mathrm{ml}$ & - \\
Test sample & - & $0.1 \mathrm{ml}$ \\
Horse serum & $0.1 \mathrm{ml}$ & - \\
Buffer* & $0.1 \mathrm{ml}$ & $0.2 \mathrm{ml}$ \\
Anti-POA coated bead & 1 piece & 1 piece \\
$(* 0.02$ M PBS. pH 7.3. with 1\% BSA) & \\
\hline
\end{tabular}

\begin{tabular}{|l|l|}
\hline & $\begin{array}{l}\text { incubate tor } 12 \text { hours at } 37^{\circ} \mathrm{C} \\
\text { wash } 4 \text { times with } 2 \mathrm{ml} 0.85 \% \text { saline solution }\end{array}$ \\
\hline Anti- POA conjugated peroxidase & $0.3 \mathrm{ml}$ \\
\hline
\end{tabular}

incubate for 3 hours at $37^{\circ} \mathrm{C}$

wash 4 times with $2 \mathrm{ml} 0.85 \%$ saline solution transfer the glass beads to new tubes

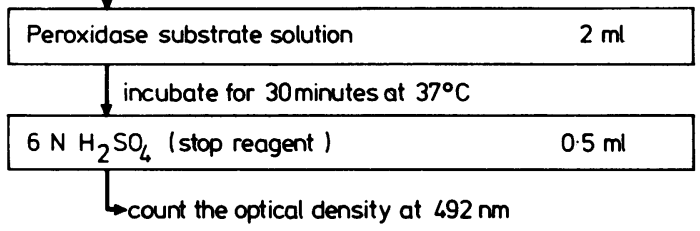

Fig. 2 The assay procedure of POA enzyme immunoassay.

enzymatic reaction was stopped by adding $0.5 \mathrm{ml} 6$ $\mathrm{M} \mathrm{H}_{2} \mathrm{SO}_{4}$, and the absorbance of each solution was read at $492 \mathrm{~nm}$.

STANDARD CURVE

A $10^{-4}$ dilution of homogenate of fetal pancreas was used as the standard POA, and defined as containing $1 \mathrm{unit} / \mathrm{ml}$ of POA. The standard curve for each sample was made with this standard POA.

\section{Results}

SPECIFICITY OF ANTI-POA SERUM

Absorbed rabbit anti-POA serum was tested by double immunodiffusion. As shown in Figure 3, there was no reaction with normal human serum, alpha-fetoprotein (Behringwerke Ltd), carcinoembryonic antigen (Abbott Ltd), ferritin (Behringwerke Ltd) and beta-2-microglobulin (Pharmacia Ltd), while there was a clear precipitation line with human fetal pancreatic extract used as the control. The antiserum did not react with extracts of human adult liver, fetal liver, adult pancreas, and porcine fetal pancreas.

PEROXIDASE-LABELLED ANTIBODY

Figure 4 shows the elution pattern of peroxidaseconjugated antibody on Sephadex G-150 column

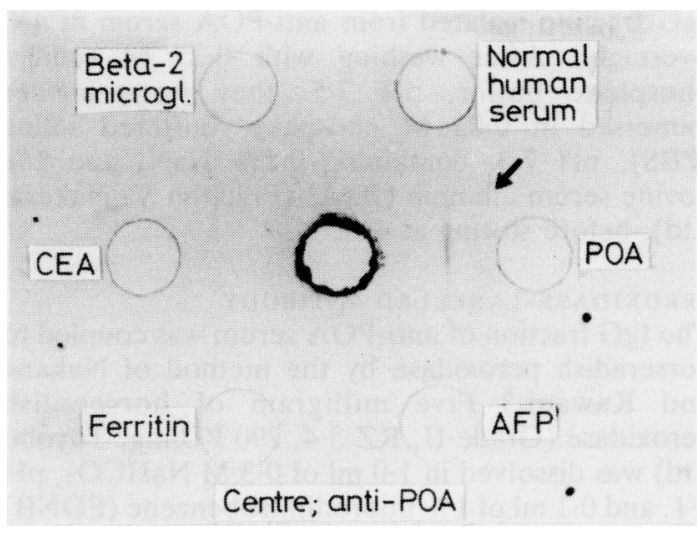

Fig. 3. Double immunodiffusion; reactions of absorbed anti-POA (centre well) to the wells of AFP, ferritin, $C E A$, beta-2-microglobulin, normal human serum and POA (fetal pancreas) (arrow: positive precipitation).

chromatography. The absorbance of the fractions was read spectrophotometrically at $280 \mathrm{~nm}$ for protein concentration and $403 \mathrm{~nm}$ for peroxidase concentration. The peroxidase-labelled antibody was obtained by collecting the fractions of the first peak. Approximately $78 \%$ of the horseradish peroxidase was found to be coupled with anti-POA IgG.

\section{STANDARD CURVE}

Figure 5 shows the standard curve for the enzyme immunoassay of POA, and covers a range from 1 unit $/ \mathrm{ml}$ to $10000 \mathrm{unit} / \mathrm{ml}$.

\section{REPRODUCIBILITY}

Tables 1 and 2 show the reproducibility of the

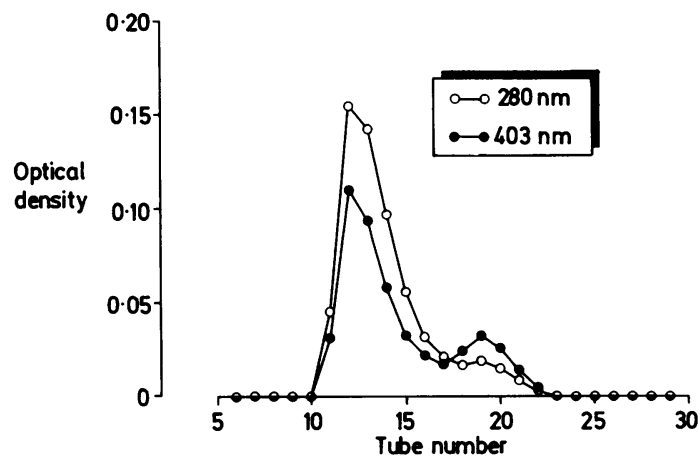

Fig. 4 An elution pattern of anti-POA conjugated with horseradish peroxidase on Sephadex G-150 column chromatography. 


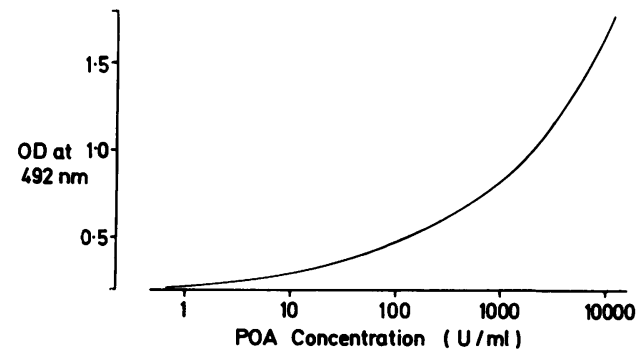

Fig. 5 Standard curve for POA enzyme immunoassay.

enzyme immunoassay which was obtained by carrying out repeated assays using 11 samples (sample A-K). The intra-assay coeficients of variation $(\mathrm{CV})$ ranged from $7 \cdot 7-17 \cdot 3 \%$, and the inter-assay $\mathrm{CV}$ ranged from $2 \cdot 7-23 \cdot 1 \%$.

\section{RECOVERY}

Recovery of added POA was assessed by assaying samples to which serum with a known POA concentration had been added. The recovery ranged from $90 \cdot 7-101 \cdot 1 \%$ with an average of $96 \cdot 2 \%$.

\section{SERUM POA CONCENTRATIONS IN PANCREATIC}

CANCER AND OTHER DISEASES

Figure 6 shows the serum POA concentrations in the 169 cases examined. The mean serum POA concentration in the normal controls was $763 \pm 51$ unit $/ \mathrm{ml}$ (mean \pm SEM), and $755 \pm 91$ unit $/ \mathrm{ml}$ in patients with benign miscellaneous diseases, $749 \pm 87$ unit $/ \mathrm{ml}$ in patients with malignancy other than pancreas, and $784 \pm 116 \mathrm{unit} / \mathrm{ml}$ in chronic pancreatitis. The serum POA concentration in patients with pancreatic cancer varied from 940$2930 \mathrm{unit} / \mathrm{ml}$ with a mean value $( \pm$ SEM) of 2006 $( \pm 122) \mathrm{unit} / \mathrm{ml}$, and was significantly higher than that of other groups $(\mathrm{p}<0.001$, two sample rank test).

Abnormal POA concentrations above 1500 unit/ $\mathrm{ml}$ accounted for $81 \%(17 / 21)$ of pancreatic cancer,
Table 1 Intra-assay reproducibility of POA enzyme immunoassay ( $n=3$, sample $A-C)$

\begin{tabular}{llll}
\hline \multirow{4}{*}{ No } & \multicolumn{3}{l}{ POA concentration (unit/ml) } \\
\cline { 2 - 4 } & $A$ & $B$ & $C$ \\
\hline 1 & 285 & 2020 & 7070 \\
2 & 265 & 1700 & 7040 \\
3 & 248 & 2300 & 5120 \\
4 & 304 & 1700 & 5120 \\
5 & 285 & 1625 & 5000 \\
6 & 248 & 1625 & 5140 \\
7 & 285 & 1880 & 6800 \\
8 & 255 & 1860 & 7260 \\
SD & $20 \cdot 9$ & $232 \cdot 2$ & $1049 \cdot 1$ \\
m & $271 \cdot 6$ & $1838 \cdot 8$ & $6068 \cdot 8$ \\
CV & $7 \cdot 7$ & $12 \cdot 6$ & $17 \cdot 3$ \\
\hline
\end{tabular}

$2 \%(1 / 46)$ of normal controls, $16 \%(6 / 37)$ of benign miscellaneous diseases, $8 \%(3 / 37)$ of malignant miscellaneous diseases and $14 \%(4 / 28)$ of chronic pancreatitis.

\section{CHANGES OF SERUM POA CONCENTRATIONS IN PANCREATIC CANCER}

In one resectable pancreatic cancer without metastasis, the serum POA concentration increased from 1610 to $2480 \mathrm{unit} / \mathrm{ml}$ with the progress of cancer during one month before operation. After removal of the tumour from the head of the pancreas $(35 \times 25 \times 20 \mathrm{~mm})$, the POA level fell rapidly to 900 and then to $112 \mathrm{unit} / \mathrm{ml}$ after one and two months (Fig. 7).

\section{Discussion}

Oncofetal antigens ${ }^{9} 10$ such as alpha-fetoprotein ${ }^{11}$ and carcinoembryonic antigen ${ }^{12}$ are now used for the immunological diagnosis of malignancy, and immunological approaches have been investigated $^{13-16}$ to help in the early detection of pancreatic cancer. ${ }^{17}$

Pancreatic oncofetal antigen ${ }^{1}$ has been reported

Table 2 Inter-assay reproducibility of POA enzyme immunoassay ( $n=8$, sample $D-K)$

\begin{tabular}{|c|c|c|c|c|c|c|c|c|}
\hline \multirow[b]{2}{*}{ No } & \multicolumn{8}{|c|}{ POA concentration (unit/ml) } \\
\hline & $D$ & $E$ & $F$ & $G$ & $H$ & $I$ & $J$ & $K$ \\
\hline $\begin{array}{l}1 \\
2 \\
3\end{array}$ & $\begin{array}{l}760 \\
600 \\
620\end{array}$ & $\begin{array}{l}860 \\
746 \\
810\end{array}$ & $\begin{array}{r}1033 \\
824 \\
1100\end{array}$ & $\begin{array}{l}2220 \\
2350 \\
1485\end{array}$ & $\begin{array}{l}2720 \\
2860 \\
2750\end{array}$ & $\begin{array}{l}2930 \\
3570 \\
2750\end{array}$ & $\begin{array}{l}3280 \\
2670 \\
3780\end{array}$ & $\begin{array}{l}3830 \\
3280 \\
3200\end{array}$ \\
\hline $\begin{array}{l}\text { SD } \\
m \\
C V\end{array}$ & $\begin{array}{r}87 \cdot 2 \\
660 \cdot 0 \\
13 \cdot 2\end{array}$ & $\begin{array}{r}57 \cdot 1 \\
805 \cdot 3 \\
7 \cdot 1\end{array}$ & $\begin{array}{r}144 \cdot 0 \\
985 \cdot 7 \\
14 \cdot 6\end{array}$ & $\begin{array}{r}466 \cdot 4 \\
2018 \cdot 3 \\
23 \cdot 1\end{array}$ & $\begin{array}{r}73.7 \\
2776.7 \\
2.7\end{array}$ & $\begin{array}{r}431 \cdot 0 \\
3083 \cdot 3 \\
14 \cdot 0\end{array}$ & $\begin{array}{r}555 \cdot 9 \\
3243 \cdot 3 \\
17 \cdot 1\end{array}$ & $\begin{array}{r}343 \cdot 0 \\
3436 \cdot 7 \\
10 \cdot 0\end{array}$ \\
\hline
\end{tabular}




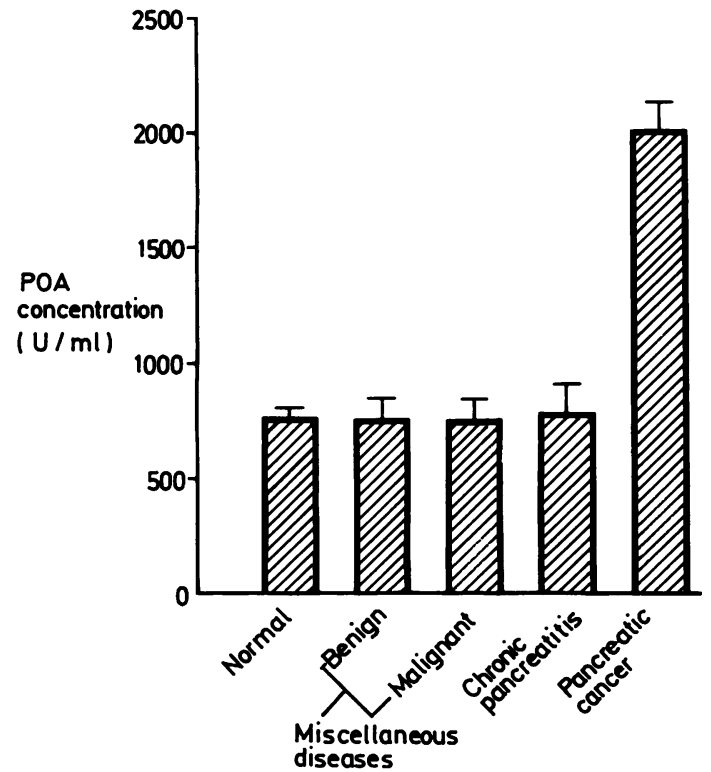

Fig. 6 Serum POA concentrations in pancreatic cancer and other diseases (mean and standard error).

to be a valuable tumour marker for pancreatic cancer. ${ }^{2}{ }^{18}$ Clinical trials carried out to detect POA in the pancreatic juice ${ }^{2}$ or in the serum ${ }^{19} 20$ have been made by double immunodiffusion and counterimmunoelectrophoresis. Gelder et $a l^{21}$ have reported that serum POA concentrations were

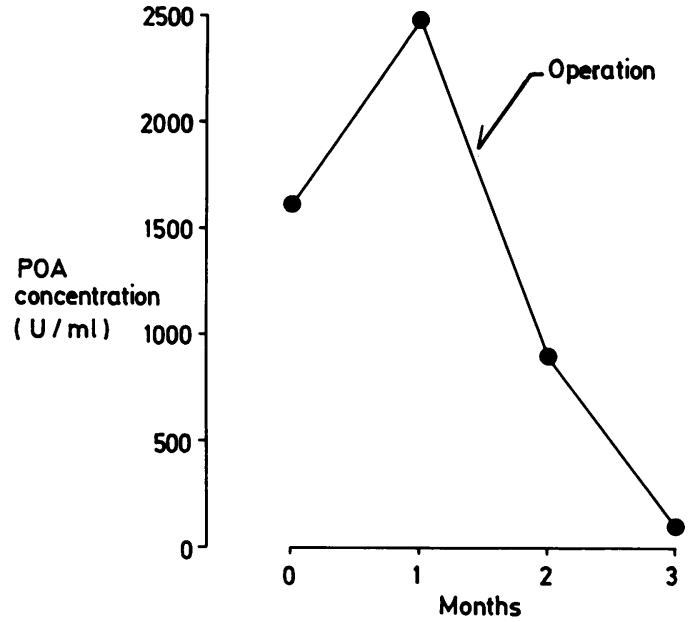

Fig. 7 Changes of serum POA concentrations in a resectable pancreatic cancer. raised in $48 \%$ of patients with pancreatic cancer using rocket immunoelectrophoresis assay. A more sensitive assay method is required, however, to detect minute amounts of POA for early diagnosis.

We have developed an enzyme immunoassay ${ }^{22}$ for POA, which is a safe and sensitive quantitative assaying method with several advantages, as the procedure is simple and radioisotopes are not used.

Reproducibility studies of the established assay gave coefficients of variation of an average of $12.5 \%$ for intra-assay, and $12.7 \%$ for inter-assay, and the recovery test of the assay showed satisfactory results. These results indicate that the enzyme immunoassay used could be applicable in the preliminary measurement of serum POA concentrations.

Using the enzyme immunoassay, significantly raised serum POA concentrations were observed with a relatively high specificity in patients with pancreatic cancer, compared with those in chronic pancreatitis, other various diseases, or normal controls.

Although there was about $20 \%$ false negative rate and $10 \%$ false positive, the enzyme immunoassay of POA would be one of the useful aids in detecting the patients with cancer of the pancreas, and the estimation of serum POA could be combined with other morphological examinations such as ultrasonic tomography, computed tomography, endoscopic retrograde cholangio-pancreatography (ERCP), or angiography.

We conclude that POA would be the useful marker of pancreatic cancer, and the enzyme immunoassay of POA would be valuable in the diagnosis of pancreatic cancer.

The authors wish to thank Professor Dr H G Thiele, and Professor Dr M Classen for their suggestions for preparing the anti-POA serum, and thank Dr W G Wilson for the preparation of the manuscript.

\section{References}

1 Banwo O, Versey J, Hobbs JR. New oncofetal antigen for human pancreas. Lancet 1974; 1: 643-5.

2 Nishida K, Kondo M, Jessen K, Classen M. Diagnosis of pancreatic cancer by pancreatic oncofetal antigen (POA) in pure pancreatic juice. HepatoGastroenterology 1981; 28: 102-5.

3 Nishida K, Sugiura M, Yoshikawa T, Kondo $M$. Enzyme immunoassay of pancreatic oncofetal antigen as test for pancreatic cancer. Lancet 1980; 1: 262-3.

4 Avrameas $S$, Ternynik $T$. The crosslinking of proteins 
with glutaraldehyde and its use for the preparation of immunoadsorbents. Immunochemistry 1969; 6: 53-66.

5 Heide K, Schwick HG. Salt fractionation of immunoglobulins. In: Weir DM, ed. Handbook of experimental immunology, vol. 1. Oxford: Blackwell Scientific Publications, 1978: 7.1-7.11.

6 Fahey JL, Terry EW. Ion exchange chromatography and gel filtration. In: Weir DM, ed. Handbook of experimental immunology. Vol. 1. Oxford: Blackwell Scientific Publications, 1978; 8.1-8.16.

7 Hamaguchi Y, Kato K, Fukui H, Schirakawa I, Kobayashi K, Katunuma N. Enzyme-linked sandwich immunoassay of ornithine $\sigma$-aminotransferase from rat liver using antibody-coupled glass rods as solid phase. $J$ Biochem 1976; 80: 895-8.

8 Nakane PK, Kawaoi A. Peroxidase-labeled antibody a new method of conjugation. J Histochem Cytochem 1974; 22: 1084-91.

9 Alexander P. Foetal "Antigens" in cancer. Nature 1972; 235: 137-40.

10 Chism SE, Burton RC, Warner NL. Immunogenicity of oncofetal antigens: a review. Clin Immunol Immunopathol 1978; 2: 346-73.

11 Tatarinov YS. Content of embryo-specific alphaglobulin in the blood serum of human foetus, new born and adult man in primary cancer of the liver. Vopr Med Khim 1965; 2: $20-4$.

12 Gold P, Freedman SO. Specific carcinoembryonic antigens of the human digestive system. $J$ Exp Med 1965; 122: 467-81.
13 Taguchi K. Immunologic detection of primary carcinoma of the pancreas. Can J Surg 1978; 21: 313-5.

14 Kuntz DJ, Archer SJ. Extraction and identification of a human pancreatic-tumor-associated antigen. Oncology 1979; 36: 134-8.

15 Schultz DR, Yunis AA. Tumor-associated antigen in human pancreatic cancer. J Natl Cancer Inst 1979; 62: 777-85.

16 Nishida K, Yoshikawa T, Kondo M, Thiele HG. Immunological diagnosis of pancreatic cancer by assaying carcinoembryonic antigen (CEA) in pure pancreatic juice. Hepato-Gastroenterology 1980; 27: 488-94.

17 Cohn I Jr. Cancer of the pancreas. Detection and diagnosis. Cancer 1976; 37: 582-8.

18 Wood RAB, Moossa AR. The prospective evaluation of tumor-associated antigens for the early diagnosis of pancreatic cancer. Br J Surg 1977; 64: 718-20.

19 Gelder F. Moossa A. Evaluation of a pancreatic oncofetal antigen (POA). [Abstract] Fed Proc 1976; 35: 758.

20 Mihas AA. Immunologic studies on a pancreatic oncofetal protein. J Natl Cancer Inst 1978; 60: 1439-44.

21 Gelder FB, Reese CJ, Moossa AR, Hall T, Hunter R. Purification, partial characterization and clinical evaluation of pancreatic oncofetal antigen (POA). Cancer Res 1978; 38: 313-24.

22 Schuurs AHWM, Van Weemen BK, Enzyme immunoassay. [Review] Clin Chim Acta 1977; 81: $1-40$. 